\title{
Potential of Patikan Kerbau (Euphorbia hirta) as Antibacterial on Aeromonas hydropilla and Vibrio alginolitycus in Fish Culture
}

\author{
Yuliana Salosso \\ Faculty of Marine Sciences and Fisheries, University of Nusa Cendana Kupang, Indonesia
}

Yudiana Jasmanindar

Faculty of Marine Sciences and Fisheries, University of Nusa Cendana Kupang, Indonesia

Received: November 18, 2013 Accepted: December 31, 2013 Published: January 15, 2014

doi:10.5296/ast.v2i1.4916 URL: http://dx.doi.org/10.5296/ast.v2i1.4916

\begin{abstract}
The aims of this study were to find out the potential of Patikan kerbau (Euphorbia hirta) as antibacterial on Aeromonas hydropilla and Vibrio alginolyticus. Phytochemical study on E. hirta leaves was carried out to determine the chemical compounds group and resulted in the presence of phenolic, terpenoid and tannin group in the leaves. The antibacterial assay by diffusion agar using paper disc showed that methanol and aqueou extract either of using dried powder leaves boiling method or fresh leaves boiling method were able to inhibit the growth of Aeromonas. hydropilla and Vibrio alginolyticus. The highest antibacterial activity against those bacteria was shown by methanol extract. The minimum inhibitory concentration (MIC) and minimum bactericidal concentration (MBC) of this methanol extract was found to be 0.156 and $0.625 \%$ by using agar dilution method. In addition, the toxicity study exhibited that treatment of cat fish (Clarias batrachus) larvae and humpback grouper (Cromileptes altivelis) larvae with $E$. hirta methanol extract at the concentration of $1 \%$ for 5 minutes did not give any toxic effect.
\end{abstract}

Keywords: Euphorbia hirta, Antibacterial, Aeromonas hydropilla, Vibrio alginolyticus, Clarias batrachus, Cromileptes altivelis 


\section{Introduction}

Bacterial disease has been a serious problem in fishery culture. Aeromonas hydropilla is one of pathogen bacterium which can attack all fresh water fishes. It is the causative agent of Motile Aeromonas Septicemia (MAS) resulting in mass mortality in fishery culture (Haniffa \& Shanthi, 2012; Maduri, 2012; Erawati \& Marsoedi, 2004). Another pathogen bacterium, Vibrio alginolyticus, has also attacked fresh and branckish water fishes and has been the causative agent of vibriosis. According to Yuasa et al. . (2000) and Dewi et al., (2002), Vibrio alginolyticus has been the main problem in fishery culture since it has given mass mortality more than $50 \%$.

Efforts to overcome these bacterial diseases have used chemicals such as formalin and malachite green as well as antibiotics, such as chloramfenicol, oxytetracyclinn and prefuran (Raffi \& Suresh, 2011). Since the bactericides have given a side effect on environment such as can accumulate in water and decrease the aquatic environmental quality and human as a consumer such as transfer pathogen to human, these treatments have become less effective (Nithikulworawong, 2012; Bhuvaneswari, 2012; Haniffa \& Shanthi, 2012). Based on the problems, some researchers have attempted other alternative methods to control the diseases.

The rapid growth of knowledge on natural products with various biological activities has provided an alternative to overcome these problems. In recent years, the natural product research has focused the work on isolation and identification of compounds for application mostly in pharmaceutical area. Euphorbia hirta is one of plants which is abundant in the tropical area. In Indonesia, E. hirta is grown among the grass on the sidewalk, gardens or the grounds of the ungroomed house and found in scattered each other (Adedapo et al., 2005; Arisandi \& Andriani, 2006). Patikan kerbau was used as traditional drug in several tropical countres such as Indonesia and Malaysia (Kader et al., 2013; Loh et al., 2009).

Mostly people used E. hirta as cure sore throat, bronchitis, asthma, stomach inflammation, dysentery, diarrhoea, blood, urinary inflammations of mammary glands, swollen breasts and eczema (Kader et al., 2013; Arisandi \& Andriani, 2006). The ability of patikan kerbau in disease prevention is due to the existence of its bioactive compounds such as Flavanoid and tannin (kader et al., 2013; upadhyay et al., 2010; Poornima \& Prabakaran, 2012; Shih \& Cherng, 2012), saponin and steroid (Kader et al., 2013; Poornima \& Prabakaran, 2012), alkaloid and terpenoid (Kader et al., 2013; Upadhyay et al., 2010; Shih \& Cherng, 2012). E. hirta was also reported to have antibacterial (Kader et al, 2013; Upadhyay et al., 2010; Jyothirmayi \& Prasad, 2011; Titilope et al., 2012; Poornima \& Prabakaran, 2012; Mamun-or-Rashid et al., 2013; Shih \& Cherng, 2012), antifungal (Jyothirmayi \& Prasad, 2011), anti-inflammation, antimalaria, antioxidant, anti-tumor, larvacidal and molluscicidal activity (Mamun-Or-Rashid et al., 2013; Shih \& Cherng, 2012).

E. hirta has been used for disease prevention on huma. Nevertheless, this plant has not been used as antibacterial on fishery culture. Therefore, to increase the economical value of $E$. hirta and to search a new source of drugd as antibiotics instead in fishery culture it need to study potential of Patikan kerbau as antibacterial on A. hydropilla and Vibrio alginolyticus through determination of its chemical compound group and toxicity on cat fish (Clarias 
batrachus) larvae and humpback grouper (Cromileptes altivelis) larvae.

\section{Materials and Methods}

\subsection{Collection and Phytochemical Study}

E. hirta was collected from Kupang City, East Nusa Tenggara province, Indonesia. Patican E. hirta were separated, cleaned and dried under room temperature. Dried E. hirta leaves then were ground to powder form. A part of powder form was used for phytochemical study and the rest was used for extraction work. Alkaloid test used Culvenor-Fiztgerald method, saponin test used saponification test and phenolic test was carried oud by addition of $\mathrm{FeCl}_{3}$. Moreover, terpenoid and steroid test was done by Lieberman-Burchard method (Wibowo et al., 2008; Jagessar \& Cox, 2010).

\subsection{Extraction of E. hirta}

Fifty gram of powder form leaves was soaked in $500 \mathrm{~mL}$-heksane $(1: 10)$ for overnight and filtered through Whatmann No.1 filter paper fitted in a Buchner funnel using suction. Filtrate obtained was evaporated under reduce pressure by a rotary evaporator (Buchi-type) to get n-hexane crude extract and residue was extracted with $500 \mathrm{~mL}$ ethyl acetate for overnight and filtered. Filtrate was then evaporated to yield ethyl acetate crude extract. Residue was again soaked with $500 \mathrm{~mL}$ methanol for overnight, filtered and evaporated to give $10 \mathrm{~mL}$ metanol crude extract by using vacuum evaporator (Salosso \& Jasmanindar, 2009).

A part of dried powder form leaves $(50 \mathrm{~g})$ was added with $500 \mathrm{~mL}$ distilled water and boiled. Aqueous extract was then precipitated overnight, filltered and evaporated to get $10 \mathrm{~mL}$ aqueous crude extract (Salosso \& Jasmanindar, 2009). Aqueous extract was also obtained from boiling of cutted fresh E. hirta leaves and boiled to be continued filtering through Whatmann No.1 filter paper fitted in a Buchner funnel using suction and collected for concentrated under reduce pressure by a rotary evaporator (Buchi-type) to yield aqueous extract crude extract (Salosso, 2012).

\subsection{Antibacterial Assay}

All extracts (n-hexane, ethyl acetate, methanol, and both aqueous extracts) of Patikan Kerbau leaves were tested their antibacterial against A. hydropilla and $V$. alginolitycus by agar diffussion using paper discs at the concentration of $30 \mathrm{mg} / \mathrm{mL}$. The target bacteria were cultured by using TSA (Triptic Soy Agar) and incubated at $37{ }^{0} \mathrm{C}$ for 24 hours. The bacteria are prepared by suspending in $10 \mathrm{ml}$ of sterile water. The concentration of bacteria is adjusted in sterile water to match the density of a $0.5 \mathrm{McFarland}$ Standard. The filter paper discs (6 $\mathrm{mm}$ in diameter) were individually impregnated with $20 \mu \mathrm{L}$ of the all crude extracts (30 $\mathrm{mg} / \mathrm{mL}$ ) and $20 \mu \mathrm{L}$ of the solven controls (n-hexane, ethyl acetate, methanol, and distilled water) dried in a laminar air flow and then placed onto the TSA plates previously inoculated with the tested microorganisms. The plates were incubated at $37^{\circ} \mathrm{C}$ for $24 \mathrm{~h}$. The presence of inhibition was indicated by the occurrence of clear inhibition zone around the disc. 
2.4 Determination of Minimum Inhibitory Concentration (MIC) and Minium Bactericidal Concentration (MBC)

Methanol extract of E. hirta leaves was obtained to give the highest antibacterial activity against $A$. hydropilla and $V$. alginolitycus and was continued to determine its minimum inhibitory concentration (MIC) and minimum bactericidal concentration (MBC) by using agar dilution method. Ten sterile tubes were prepared in which the first tube was added with $10 \mathrm{~mL}$ Nutriet Broth (NB), whilst the second until the tenth tube were added with $5 \mathrm{~mL}$ Nutrien Broth (NB). The first tube was added methanol extract until reach the concentration of $10 \%$. From this concentration, a serial two fold dilution was prepared to give the concentrations of $5 \%, 2.5 \%, 1.25 \%, 0.625 \%, 0.313 \%, 0.16 \%$, and $0 \%$. One loop of A. hydropilla and $V$. alginolyticus was separately mixtured into NB in the all tube except the ninth and tenth tube. In the ninth tube, it only contained NB whilst, in the tenth tube, it contained NB plus aqueous extract without bacteria. All tube tested were vortexed and incubated at $37^{\circ} \mathrm{C}$ for 24 hours. After 24 hours, $20 \mu \mathrm{L}$ filtrate of each tube was spread on TCBSA and incubated at $37^{\circ} \mathrm{C}$ for 24 hours. The presence of growth inhibition was indicated by the absence of bacterium colony growth on TCBSA. The lowest concentration which was able to inhibit the growth of bacteria until 24 hours and after 48 hours the bacteria regrew was determined as MIC. Meanwhile, the lowest concentration which was able to kill bacteria (no bacteria grew after 48 hours) was determined as MBC.

\subsection{Toxicity Test of E. hirta Active Methanol Extract on Cat Fish (C. batrachus) Larvae and Humpback Grouper (C. altivelis)}

8-10 cm of cat fish (C. batrachus) larvae and 7-10 cm of and humpback grouper (C. altivelis) larvae obtained from Balai Benih Ikan Noekele, Kupang and BBAP Takalar, South Sulawesi, Indonesia, respectively were used as tested animals. The culture density was 6 fish/20 liter of water. Acclimatization process was conducted for 3 to 4 days in the rearing water preceding the experiment. On the first day of toxicity test, Fish larvae were treated with the active Patikan kerbau leaves methanol extract at the concentrations of $10.0 \%, 1.0 \%$ and $0.1 \%$ in steril sea water $30 \mathrm{ppt}$. Thereafter, the observation of soaking time was carried out untill fish larvae died. From the data of soaking time which caused died fish larvae was determined the appropriate fish larvae soaking time period for each concentration of the active methanol extract. Experiment was continued on fish larvae treated with the active methanol extract at those concentrations at the soaking time period obtained 5 minutes in which in this time, fish larva did not show any mortality. Fish larvae treated with the active aqueous extract at those concentrations by using bath method were reared in another aquarium with the density of 6 fish/10 L water for 7 days

\section{Results and Discussions}

\subsection{Phytochemical Test}

Phytochemical study on E. hirta leaves showed the presence of fenolic, flavanoid, tanin and triterpenoid group (Table 1), which have potential to be developed as antibacterial in fishery culture. E. hirta collected from different countries has the different bioactive compounds. Flavanoid, tannin and fenolic were obtained from E. hirta collected from Malaysia (Kader et 
al., 2013), Jaipur india (Upadhyay et al., 2010) Tamiluede India (Poornima \& Prabakaran, 2012) and Cina (Shih \& Cherng, 2012). Meanwhile, saponin and steroid were only isolated from Patikan Kerbau collected from Malaisia (Kader et al., 2013) and Tamiluede India (Poornima \& Prabakaran, 2012) and alkaloid and terpenoid were found to be contained in $E$. hirta collected from Malaysia (Kader et al., 2013), Jaipur India (Upadhyay et al., 2010) and Cina (Shih \& Cherng, 2012).

Table 1. Compounds group from E. hirta leaves

\begin{tabular}{ll}
\hline Compound group & Result \\
\hline Phenolic & + \\
Flavonoid & + \\
Alkaloid & - \\
Steroid & - \\
Triterpenoid & + \\
Saponin & - \\
Tannin & + \\
\hline
\end{tabular}

\subsection{Antibacterial Activity of E. hirta Extracts}

The antibacterial activity test of all extracts from $E$. hirta leaves exhibited that methanol and aqueous extract of this plant were able to inhibit the growth of $A$. hydropilla and $V$. harveyi indicated by the presence of clear inhibition zone around paper disc (Table 2 and Figure 1). The formed inhibition zone is the ability measure of antimicrobe compounds against target bacteria. Inhibition around paper disc is depended on diffusion of antibacterial compounds used. If the antimicrobe compounds has a function for inhibiting, the bacteria growth will stop and give a clear inhibition zone around paper disc after incubation for 18-24 hours (Fadjar et al., 2005).

The strong antibacterial activity of plant is commonly effect of solvent polarity used in the extraction process. In this study, methanol extract of E. hirta leaves showed the higher inhibition zone than that of aqueous extract (Table 2). It indicated that the antibacterial compounds of E. hirta leaves were concentrated in methanol extract. The antibacterial activity of bioactive compounds is caused by several factors such as fuctional group activity, resistence of bacteria on bioactive compounds, concentration of bioactive compounds, and the density of bacteria (Mallawa \& Halid, 2006). 


\section{Macrothink}

Aquatic Science and Technology

ISSN 2168-9148 2014, Vol. 2, No. 1

Table 2. The antibacterial activity of all extracts of E. hirta leaves against A. hydropilla and V.alginolitycus

\begin{tabular}{llll}
\hline No & Extract & A. hydropilla & V.alginolitycus \\
\hline 1 & Aqueous extract of fresh leaves & + & + \\
2 & Methanol extract & + & + \\
3 & n-Heksane extract & - & - \\
4 & Ethyl acetate extract & - & - \\
5 & Aqueous extract of dried powder & + & + \\
& form leaves & & \\
6 & Solvent $(-)$ control & - & - \\
7 & Streptomycine $((+)$ control $)$ & + & + \\
\hline
\end{tabular}

Note : +: Inhibition zone; -: No inhibition.
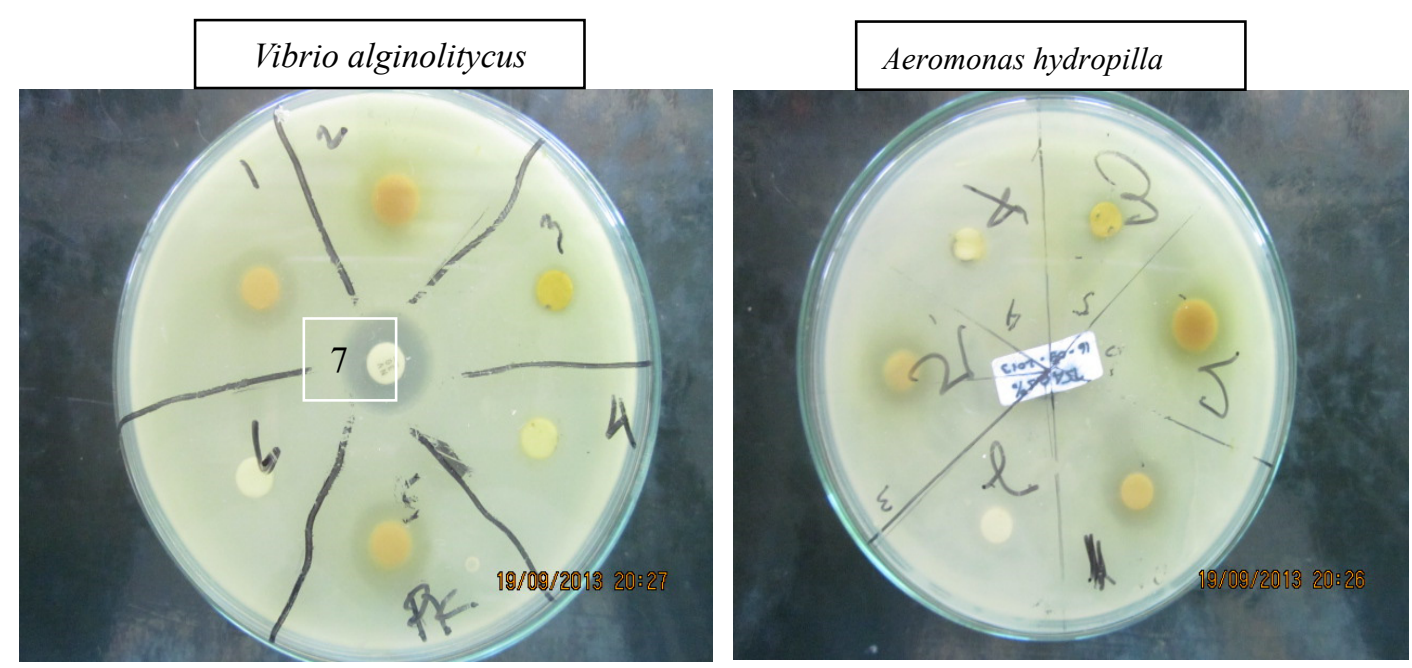

1. Aqueous extract of fresh leaves

5. Aqueous extract

2. Methanol extract

6. Solvent (without extract)

3. n-Heksane extract

4. Ethyl acetate extract

7. Streptomycine (positive control)

Figure 1. Inhibition zone of E. hirta extracts on $V$. alginolyticus and A. hydropilla

\subsection{Determination of Methanol Extract Minimum Inhibitory Concentration (MIC) and} Minimum Bactericidal Concentration (MBC)

Minimum Inhibitory concentration (MIC) and Minimum Bactericidal Concentration (MBC) of E. hirta leaves methanol extract by using agar dilution method was shown in Table 3.

From the Table 3 it can be seen that the minimum inhibitory concentration (MIC) of E. hirta Leaves methanol extract was $0.156 \%$ on $V$. alginolitycus and A. hydropilla. It was indicated by the presence of the target bacteria growth after 48 hours incubation meaning that at this concentration, methanol extract of this plant was bacteriostatic. Meanwhile, minimum 


\section{Macrothink

bactericidal concentration (MBC) of this plant methanol extract was $0.625 \%$ indicated by the absence of the target bacteria growth after 48 hours incubation meaning at this concentration, methanol extract of this plat was bactericide. The low MIC value exhibited by this methanol extract showed that E. hirta leaves strongly inhibited the growth of both bacteria. The antibacterial activity of E. hirta was earlier reported by Hamdiyati et al., (2008). They found that E. hirta leaves extract was able to inhibit the growth of Staphylococcus epidermis at the concentration of $20 \mathrm{mg} / \mathrm{mL}$. Ogbulie et al., (2007) also reported that this plant leaves extract gave an antibacterial against Staphylococliercus aureus, Escherichia coli, Pseudomonas aeruginosa, Salmonella typhi and Bacillus subtilis at the concentrations of 50, 100, 150, 200, and $250 \mathrm{mg} / \mathrm{mL}$. Furthermore, E. hirta leaves extract was also obtained to give an antibacterial activity against $S$. aureus dan $P$. aeruginosa dengan MIC (Minimum Inhibitory Concentration) value of $2 \mathrm{mg} / \mathrm{mL}$ (Ngemenya et al., 2006). In addition, Assidqi et al., (2012) proved that this plant leaves extract showed a strong antibacterial activity towards $A$. hydrophila in fish culture with the MIC value of $0,156 \%$ and MBC value of $0,312 \%$.

Table 3. Minimum Inhibitory Concentration (MIC) and Minimum Bactericidal Concentration (MBC) of E. hirta leaves methanol extract

\begin{tabular}{lllll}
\hline \multirow{2}{*}{$\begin{array}{l}\text { Concentration } \\
\mathbf{\%})\end{array}$} & \multicolumn{2}{l}{ Vibrio alginolitycus } & \multicolumn{2}{l}{ Aeromonas hydropilla } \\
\cline { 2 - 5 } & MIC & MBC & MIC & MBC \\
\hline 10.000 & - & - & - & - \\
5.000 & - & - & - & - \\
2.500 & - & - & - & - \\
1.250 & - & - & - & - \\
0.625 & - & - & - & - \\
0.313 & - & + & - & + \\
0.156 & - & + & - & + \\
0.078 & + & + & - & + \\
Bacteria control & + & + & + & + \\
Extract control & - & - & - & - \\
\hline
\end{tabular}

Note: - Inhibition zone.

3.4 Toxicity Test of E. hirta Leaves Methanol Extract on Cat Fish (C. batrachus) Larvae and Humpback Grouper (C. altivelis) Larvae

Toxicity test of $E$. hirta leaves methanol extract on cat fish ( $C$. batrachus) larvae and humpback grouper ( $C$. altivelis) larvae was done by using bath method and the survival rate of cat fish (C. batrachus) larvae and humpback grouper (C. altivelis) larvae is shown in Table 4. 
Table 4. Survival rate of cat fish (C. batrachus) and humpback grouper (C. altivelis) larvae soaked with $E$. hirta methanol extract at different concentrations for 5 minutes

\begin{tabular}{llll}
\hline No & Concentration (\%) & Survival rate (\%) \\
\cline { 3 - 4 } & & Cat fish larvae & Humpback grouper larvae \\
\hline 1 & 10.0 & 0 & 0 \\
2 & 1.0 & 100 & 100 \\
3 & 0.1 & 100 & 100 \\
4 & Control (untreated sample) & 100 & 100 \\
\hline
\end{tabular}

Table 4 displayed that the survival rate of cat fish and humpback grouper larvae treated with E. hirta methanol extract at the concentration of $0.1-1.0 \%$ was $100 \%$. It showed that treating cat fish and humpback grouper larvae with methanol extract at these concentrations for 5 minutes did not give any toxic effect. It indicated that $E$. hirta leaves methanol extract may be an environment friendly antibacterial compounds source in fishery culture. As reported by Pelczar and Chan (2005) that one of ideal antibacterial characteristics is no toxic effect on test animal but it may kill pathogen microorganisms.

\section{Conclussion}

E. hirta leaves has the potential as an antibacterial compounds source in fish culture as its methanol extract showed a strong antibacterial activity against A. hydropilla and $V$. alginolitycus in vitro. The phytochemical study exhibited the presence of phenolic, tannin, and triterpenoid in E. hirta leaves. The antibacterial activity assay showed that methanol extract of this plant give the highest antibacterial activity against $A$. hydropilla and $V$. alginolitycus with the MIC and MBC value of 0.156 and $0.625 \%$, respectively. This methanol extract has no any toxic effect on cat fish and humpback grouper larvae at the concentrations of 0.1 and $1 \%$ for 5 minutes of bath method.

\section{References}

Assidqi, K., Tjahjaningsih, W., \& Sigit, S. (2012). Potensi Ekstrak Daun Patikan Kebo (Euphorbia hirta) Sebagai Antibakteri Terhadap Aeromonas hydrophila Secara In Vitro. Journal of Marine and Coastal Science, 1(2), 113-124.

Bhuvaneswari, R. (2012). Anti-Bacterial Activity Of Acorus Calamus And Some Of Its Derivatives Against Fish Pathogen Aeromonas Hydrophila. Indian Journal of Fundamental and Applied Life Sciences, 2(2), 191-201.

Cowan, S. T. (1985). Manual for the Identification of Medical Bacteria. London: Cambridge University Press.

Daood, N. (2011). Antibacterial activity of Some Medicinal Plants against Fish Pathogenic Aeromonas spp. Isolated from Farmed Common Carp (Cyprinus carpio). Tishreen University Journal for Research and Scientific Studies - Biological Sciences Series, 33(3).

Dewi, J., Elywatu \& Syarifuddin. (2002). Penyakit Bakterial dan Mikal (pp. 44-52). 
Lampung: Balai Budidaya Laut Lampung.

Erawati, C. I., \& Marsoedi. (2004). Pengaruh pemberian Perasan Kasar Daun pepaya (Carica papaya) dengan Dosis Yang Berbeda terhadap Ikan Mas (Cyprinus carpio) yang Terinfeksi Bakteri Aeromonas hydrophila. Jurnal Penelitian Perikanan, 7(2).

Fadjar, M., Andayani, S., \& Faizal, M. (2009). Purifikasi Fenolic Bahan Bioaktif Hydrozoa Bougainvilla Sebagai Bakterisida terhadap Bakteri Vibrio harveyi. Jurnal Aquaculture Indonesia, 5(2), 79-83.

Hamdiyati, Y., \& Kusnadi, I. H. (2008). Aktivitas Antibakteri ekstrak Daun Patikan Kebo (Euphorbia hirta) Terhadap Pertumbuhan Bakteri Staphylococcus epidermis. Jurusan Pendidikan Biologi MIPA, 12(2).

Haniffa, M. A., \& Kavitha, K. (2012). Antibacterial activity of medicinal herbs against the fish pathogen Aeromonas hydrophila. Journal of Agricultural Technology, 8(1), 205-211.

Kader, J., Noor, H. M., Radzi, S. M., \& Wahab, N. A. A. (2013). Antibacterial activities and phytochemical screening of the acetone extract from Euphorbia hirta. International Journal of Medicinal Plant Research, 2(4), 209-214.

Madhuri, S., Mandloi, A. K., Govind, P., \& Sahni, Y. P. (2012). Antimicrobial activity of some medicinal Plants against Fish Pathogens. Pandey Govind et al. IRJP, 3(4).

Mallawa, S. C. I., \& Halid, I. (2006). Aktivitas Bakteri Senyawa Bioaktif Spons laut terhadap Stahylococus aereus dan Vibrio cholerae. Jur. Lutjanus, 11(1).

Mamun-Or-Rashid, A. N. M., Mahmud, S., Towfique, N, Md., \& Sen, M. (2013). A Compendium Ethnopharmaceutical Review On Euphorbia hirta L. Ayurpharm Int J Ayur Alli Sci., 2(2), 14-21.

Ngemenya, N. M., James, A. M., Tane, P., \& Vincent, P. K. T. (2006). Antibacterial Effects of Some Cameroonian Medicinal Plants Against Common Pathogenic Bacteria. African Journal of Traditional Complementary and Alternative Medicines, 3(2), 84-93. http://dx.doi.org/10.4314/ajtcam.v3i2.31161

Nithikulworawong, N. (2012). Antibacterial Activity of Bauhinia sirindhorniae Extract Against Aeromonas hydrophila Isolated from Hybrid Catfish. Walailak J Sci \& Tech, 9(3), 195-199.

Ogbulie, J. N., Ogueke, C. C., Okoli, I. C., \& Anyanwu, B. N. (2007). Antibacterial Activities and Toxicological Potentials of Crude Ethanolic Extracts of Euphorbia hirta. African Journal of Biotechnology, 6(13), 1544-1548.

Poornima, \& Prabakaran, R. (2012). Preliminary Phytochemical Screening and Antibacterial Activity of Acalypha indica and Euphorbia hirta of Family Euphorbiaceae Against some Patogenic Organisms. International Journal of Agricultural Sciences, 2(10), 34-38.

Raffi, S. M., \& Suresh, T. V. (2011). Screening of chloramphenicol in wild and cultured shrimp Penaeus monodon by competitive enzyme linked immunosorbent assay. In 
International Conference on Chemical, Biological and Environment Sciences (ICCEBS'2011), Bangkok.

Salosso, Y. (2012). Uji Aktivitas Antibakteri Delapan Jenis Tanaman Obat Tradisonal Terhadap Bakteri A.hydropilla secara In Vitro. Buletin Penelitian dan Pengembangan Alumni IAEUP Undana, 13(1).

Salosso, Y., \& Jasmanindar, Y. (2009). Antivitas Antibakteri Ekstrak Daun Pepaya, Daun ubi jalar, Daun Jambu Biji terhadap bakteri Aeromonas hydropilla secara In Vitro. Buletin Penelitian dan Pengembangan Alumni IAEUP Undana, 10(1).

Shih, M. F., \& Cherng, J. Y. (2012). Potential Applications of Euphorbia hirta in harmacology. Drug Discovery Research in Pharmacognosy. Edited by Prof. Omboon Vallisuta. Publisher InTech.

Steinmann, V. W. (2003). Euphorbia Nocens, Formerly a Variety Of Euphorbia hirta (Euphorbiaceae). Acta Botanica Mexicana, 64, 37-44.

Taufiq, H. L., Wahyuningtyas, N., \& Wahyuni, A. S. (2008). Efek Antiinflamasi Ekstrak Patikan Kebo (Euphorbia hirta L) Pada Tikus Putih Jantan. PHARMACON, 9(1), 1-5.

Titilope, K. K., Rashidat, E. A., Christiana, O. C., Kehinde, E. R., Omobolaji, J. N., \& Olajide, A. J. (2012). In-vitro antimicrobial activities of Euphorbia hirta against some clinical isolates. Agriculture And Biology Journal Of North America. http://dx.doi.org/10.5251/abjna.2012.3.4.169.174

Upadhyay, B., Singh, K. P., \& Kumar, A. (2010). Pharmacognostical And Antibacterial Studies Of Different Extracts Of Euphorbia Hirta L. Journal of Phytology, 2(6), 55-60.

Yuasa, K., Koesharyani, I., \& Zafran. (2000). Control of Cryptocaryon infection in cultured humpback grouper Cromileptes altivelis broodstock. In Aquatic Animal Health for Sustainability, Book of Abstracts, OP 59, Fourth Symposium on Diseases in Asian Aquaculture, November 22-26, 1999, Cebu, Philippin.

\section{Copyright Disclaimer}

Copyright reserved by the author(s).

This article is an open-access article distributed under the terms and conditions of the Creative Commons Attribution license (http://creativecommons.org/licenses/by/3.0/). 